\title{
SERVICE QUALITY, BRAND TRUST, AND BRAND LOYALTY
}

\author{
Ana Mariana ${ }^{1}$, Bram Hadianto ${ }^{* 2}$, Catherine Suyanto ${ }^{3}$ \\ ${ }^{1,2,3)}$ Management Department, Business Faculty, Maranatha Christian University, Bandung \\ *Corresponding author: tan_han_sin@hotmail.com
}

\begin{abstract}
Abstrak
Penelitian ini bermaksud untuk menginvestigasi dan menganalisis pengaruh kualitas pelayanan terhadap kepercayaan merek dan kepercayaan merek terhadap kesetiaan merek dengam memakai penggguna produk Precious One sebagai objek dan populasinya. Berdasarkan tujuan ini, maka penelitian ini didesain secara kuantitatif. Oleh karena itu, kami mengambil sampel dengan metode penyampelan acak sederhana. Menurut rumus Isaac dan Michael, sampel seharusnya berjumlah 344. Namun, hanya 251 pengguna merespon untuk mengisi kuesioner ini sehingga tingkat partispasinya yaitu 75,45\%. Selanjutnya, kami memakai analis faktor konfirmatori untuk memvalidasi respon, analisis Cronbach Alpha untuk menguji kehandalan respon, dan model persamaan struktural berbasis kovarian untuk menguji hipotesis terkait. Sebagai kesimpulan, kami menemukan kualitas pelayanan berpengaruh terhadap kepercayaan merek. Tanda positif ini terdapat juga pada hubungan kausalitas antara kepercayaan merek dan kesetiaan merek. Dengan demikian, kualitas pelayanan dibutuhkan bagi Precious One untuk membagun kepercayaan yang menciptakan kesetiaan merek.
\end{abstract}

Kata Kunci: kesetiaan merek, kepercayaan merek, memposisikan pasar target, kualitas pelayanan

\begin{abstract}
This study plans to investigate and analyze the influence of service quality on brand trust and brand trust on brand loyalty by utilizing the Precious One users as the object and population. Based on this goal, this study is designed quantitatively; thus, we grab the samples by simple random sampling. According to the Isaac and Michael formula, the total pieces should be 344. However, 251 users respond to filling the questionnaire; hence, the participating rate is $75.45 \%$. Moreover, we use confirmatory factor analysis to validate the responses, the Cronbach Alpha analysis to test response reliability, and the structural equation model based on covariance to examine the related hypotheses. Overall, we find that service quality positively affects brand trust. Also, this positive sign is available in the causal relationship between brand trust and brand loyalty. Hence, the service quality is vital for Precious One to commit to building brand trust, creating brand loyalty.
\end{abstract}

Keywords: brand loyalty, brand trust, positioning targeted market, service quality

\section{INTRODUCTION}

For a company, competing in a goods market needs segmenting, targeting, and positioning. Segmentation is how the company utilizes the varied demands of a similar group of prospective customers based on their same features and responses. After that, the company has to evaluate each market segment's attractiveness and select a part of the served market. Based on the definite market selection, the company needs to strengthen product acceptance in the marketplace in the positioning stage (Setiadi, 2019).

Furthermore, to execute it, the company needs a brand for its products to be placed in the customer's mind (Tjiptono, 2011). The brand can distinguish the uniqueness of its 
offered products from its rivals (Karam \& Saydam, 2015). In the loose rivalry, the brand only functions to differ. Conversely, the brand can keep the product attractive (Aaker, 2010). Besides, the company needs loyal customers to the brand. A trustworthy person will commit to the brand and pay it at the upper price and recommend it to others. As a result, the company can increase the revenue from the sold products, charge the premium price for the marketed products, and save the operating expenses, like advertisements and distribution, for instance, to market products (Giddens \& Hofmann, 2010).

Based on the previous research facts, brand loyalty exists because of brand trust, as displayed by Zehir, Kitapçı, and Öz (2011), Kabadayi \& Alan (2012), Laroche, Habibi, Richard, and Sankaranarayanan (2012), Ahmed, Rizwan, Ahmad, and Haq (2014), Başer, Cintamür, and Arslan (2015), Etemadifard, Kafashpoor, and Zendehdel, (2016), Shin et al. (2019), Ukaj and Mullatahir (2019), Atulkar (2020), Puspaningrum (2020), Cuong (2020), and Budi, Hidayat and Mani (2021). Unfortunately, these related studies are still contrary, like Liao, Chung, Hung, and Widowati (2010) and Bennur and Jin (2016), showing no relationship.

Making the customers trust the brand is challenging. Ideally, to attain it, the company needs to serve its buyers by service quality, as displayed by Zehir et al. (2011), Alhaddad (2015), Etemadifard et al. (2016), Esmaeilpour et al. (2017), Al-Rommy \& Murtiningsih (2020), Ukaj and Mullatahir (2019), Wijaya, Surachman, and Mugiono (2020), and Wijayanti (2020). In their research, they document a positive relationship between service quality and brand trust. However, this evidence is still contrary, shown by the studies demonstrating the meaningless result (Sulistiyo, 2015; Prameka, Do, \& Rofiq, 2016).

These various facts about the research investigating two impacts encourage this study by employing the customers of the Precious One products in Indonesia. The Precious One operates under the Karya Insan Sejahtera Foundation in Jakarta. This business utilizes the disabilities to result in handiworks (Setiawati, 2016). By researching this topic, this study expects to enrich the finding related to the relationship among service quality, brand trust, and brand loyalty, especially for handicraft products made by debilities. Specifically, this research intends to attain two objectives:

1. to prove and analyze the service quality effect on brand trust;

2. to ascertain and analyze the influence of brand trust on brand loyalty.

\section{LITERATURE REVIEW}

\section{The relationship between brand trust and loyalty}

Brand trust is the customer's readiness to count on the brand. Furthermore, this trust will become essential to form brand loyalty (Lau \& Lee, 1999). Employing global brand users in Turkey, Zehir et al. (2011) demonstrate that brand trust positively affects brand loyalty. Also, Kabadayi \& Alan (2012) reveal the same proof when investigating the graduate and undergraduate students visiting the coffee store in Kocaeli. Laroche et al. (2012) confirm similar evidence after researching the social networking website's brand community members. Correspondingly, Ahmed et al. (2014) exhibit this evidence after investigating Hewlett Packard's customers in Bahawalpur, Pakistan. Similarly, Etemadifard et al. (2016) confirm this positive influence once studying Samsung products' buyers in Mashhad, Iran.

In their study, Başer et al. (2015) learn four popular brands, i.e., Apple, Coca-Cola, Nike, and Play Station, by employing the related users in Instanbul, Turkey. After testing the collected response, they confirm that brand trust is the brand loyalty antecedence with 
a positive sign. Investigating the users of the mobile telephone operators in Kosovo, Ukaj and Mullatahir (2019) prove a positive association between brand trust and its loyalty. Surveying Korean smartphone users, Shin et al. (2019) demonstrate the same situation. Also, Atulkar (2020) confirms a similar condition when inspecting the mall shoppers in two major cities in Madhya Pradesh, India.

Likewise, Puspaningrum (2020) exhibits this positive relationship between brand trust and loyalty after studying the behavior of McDonald's customers in Malang, Indonesia. Besides, Cuong (2020) finds similar proof when investigating laptop customers in Ho Chi Minh, Vietnam. In line with them, Budi et al. (2021) affirm the same pattern when learning about the Philip lamp users in West Jakarta, Indonesia. Based on several pieces of evidence, this study proposes the first hypothesis:

$\mathrm{H}_{1}$ : Brand trust positively affects brand loyalty.

\section{The relationship between service quality and brand trust}

Zehir et al. (2011) find that service quality positively influences brand trust when studying Turkey's global brand. Additionally, Alhaddad (2015) confirms this positive perceived quality effect when learning the higher institute students in business administration in Damascus, Syria. Using the users of Samsung products in Mashhad, Iran, Etemadifard et al. (2016) point out a positive influence of service quality on brand trust.

After collecting the customer responses of the Saderat Bank branches in Iran, Esmaeilpour et al. (2017) find all the service quality dimensions, covering tangibility, reliability, assurance, responsiveness, and empathy, have a positive impact on brand trust. By investigating the users of mobile phone operators in Kosovo, Ukaj and Mullatahir (2019) document the positive association between service quality and brand trust.

In their study, Al-Rommy and Murtiningsih (2020) display that brand trust is positively affected by service quality when surveying Budi Luhur university students, Jakarta, Indonesia. Additionally, after investigating the national health insurance card users in Malang, Wijyaya et al. (2020) show a positive impact. This result is supported by Wijayanti (2020), employing pizza restaurant visitors in Tangerang, Indonesia. Based on this evidence, this study proposes this second hypothesis:

$\mathrm{H}_{2}$ : Service quality positively influences brand trust.

\section{Research Model}

Based on the two hypotheses stated, the research model can be drawn and displayed in the first figure.

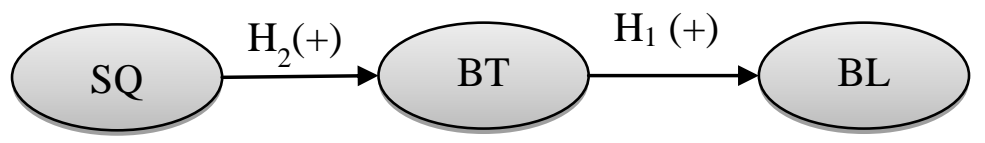

Figure 1. Research Model

Note: $\mathrm{SQ}=$ Service quality, $\mathrm{BT}=$ brand trust, $\mathrm{BL}=$ brand loyalty

\section{RESEARCH METHOD}

Three variables exist in this study, i.e., service quality, brand trust, and brand loyalty. Furthermore, we treat service quality as the exogenous variable. However, we operate brand trust and loyalty as the endogenous variable. The indicators to quantify 
service quality mention the study of Zehir et al. (2011) with some relevant modifications from Tjiptono (2019); the final result is in Table 1. We modify many items in Zehir et al. (2011) because of similar content. By combining the content from Tjiptono (2019), the substance of indicators is better to reflect tangibility (see SQ1 and SQ2), empathy (see SQ6 and SQ7), responsiveness (see SQ3), reliability (see SQ4 and SQ5), and assurance (see SQ8, SQ9, and SQ10) as the service quality dimensions.

Table 1. The Service Quality Measurement

\begin{tabular}{|l|l|c|c|}
\hline Variable & \multicolumn{1}{|c|}{ Indicators } & \multicolumn{1}{|c|}{ Scale } & Source \\
\hline Service & $\begin{array}{l}\text { The Precious One is supported by an excellent } \\
\text { physical environment (SQ1). } \\
\text { Precious One has a fair system for handling } \\
\text { complaints (SQ2). } \\
\text { The Precious One staff efficiently handles } \\
\text { customer complaints (SQ3). }\end{array}$ & $\begin{array}{c}\text { Zehir et al. } \\
\text { (2012) }\end{array}$ & \\
\cline { 2 - 4 } & $\begin{array}{l}\text { The Precious One delivers the products on } \\
\text { time as promised (SQ4). } \\
\text { The Precious One provides an accurate } \\
\text { system of order recording (SQ5) } \\
\text { The Precious One offers a flexible time for } \\
\text { me to order the products (SQ6). } \\
\text { The customer service gives special attention } \\
\text { to me (SQ7). } \\
\text { The customer service is always politely } \\
\text { speaking with me (SQ8). } \\
\text { The customer service can answer all of my } \\
\text { questions well (SQ9). } \\
\text { I feel secure when financially transacting with } \\
\text { the Precious One (SQ10). }\end{array}$ & & \\
\end{tabular}

Meanwhile, the indicators to measure brand trust and loyalty denote Laroche et al. (2012), and they are in Table 2.

Table 2. The Measurement of Brand Trust and Loyalty

\begin{tabular}{|l|l|c|}
\hline \multicolumn{1}{|c|}{ Variable } & \multicolumn{1}{|c|}{ Indicators } & \multicolumn{1}{|c|}{ Scale } \\
\hline Brand trust & $\begin{array}{l}\text { I receive something more than I hope from the } \\
\text { Precious One brand (BT1). } \\
\text { I count on the Precious One brand (BT2). } \\
\text { I am always delighted because of utilizing the products } \\
\text { with the Precious One brand (BT3). }\end{array}$ & Interval \\
\hline Brand loyalty & $\begin{array}{l}\text { After using the Precious One products, I will be } \\
\text { devoted to this brand (BT1). } \\
\text { If the Precious One brand is not available, I will search } \\
\text { for it until getting it (BL2). } \\
\text { I am ready to pay more money for the Precious One- } \\
\text { branded products (BL3). }\end{array}$ & \\
\hline
\end{tabular}


This research population is the customers purchasing the Precious One products in Indonesia, where its size (PS) is 2500. To count the representative sample (rs), we apply the Isaac and Michael formula in Sugiyono (2012) with the significance level of 5\% and the freedom degree of 1 to find the Chi-Square statistic of 3.841, P and $\mathrm{Q}$ of 0.5 , respectively (see the first equation).

$$
\mathrm{rs}=\frac{\chi^{2} \text { statistic.N.P.Q }}{d^{2}(P S-1)+\chi^{2} \text { statistic }(0.5)(0.5)}=\frac{\chi^{2} \text { statistic.N.(0.5)(0.5) }}{0.05^{2}(P S-1)+3.841(0.5)(0.5)}
$$

...(Equation 1)

By this equation, the number of samples is $\frac{3.841(2,500)(0.5)(0.5)}{0.05^{2}(2500-1)+3.841(0.5)(0.5)}=\frac{2,400.91}{7.21}=$ $333.096 \approx 334$ (rounded). Moreover, we employ the simple random sampling method to grab 334 customers as samples.

We utilize the survey to obtain data. According to Sugiyono (2012), the survey is how to get responses by allocating the questionnaires to the respondents becoming the samples. Additionally, to value the closed answers, we adopt the Likert scale consisting of five points, from one to describe the complete agreement until five to exhibit the complete disagreement.

We use the structural equation model based on covariance to analyze the data associated with variables. It is due to the latent variables and the sample size of over 200 individuals. Furthermore, the model can be found in the second equation, parts a and b.

2a)

$$
\mathrm{BL}=\beta_{1} \mathrm{BT}+\zeta_{1}
$$

(Equation

$$
\mathrm{BT}=\gamma_{1} \mathrm{SQ}+\zeta_{2}
$$

(Equation

Moreover, these latent variables require validation and reliability examinations. To test the validity, we employ the confirmatory factor analysis by comparing the loading factor of the answer on indicators with 0.5. The response is valid if the loading factors are more than 0.5 (Ghozali, 2014). Related to the reliability test, we utilize the Cronbach Alpha analysis by comparing its value, which resulted from the group of accurate answers with 0.7. The response is reliable if the Cronbach Alpha is more than 0.7 (Ghozali, 2016).

Furthermore, before estimating the model, we check its goodness of fit by some sizes, such as:

a. the Chi-Square/DF. If this value is below 5, the model is suitable for the employed data, as Ghozali (2014) exhibits;

b. the parsimony ratio. If this value is above 0.6 , the model is ideal for the data used, as Latan (2013) depicts;

c. the parsimony normed and comparative fit indexes. As long as these values are above 0.6, the model fits the utilized data, as Latan (2013) demonstrates.

\section{RESULTS AND DISCUSSION}

\section{The demographic features result}

This survey was conducted from July until November 2020 and successfully collected 251 customers, ultimately fulfilling the questionnaire. Therefore, the response rate is $251 / 344=75.45 \%$. Furthermore, 251 can be classified into age, gender, marital status, last schooling, province, and product purchase frequency (see Table 3). 
Table 3. The demographic features of the Precious One costumers participating in the survey

\begin{tabular}{|c|c|c|}
\hline Demographic feature & Description & Total \\
\hline \multirow[t]{5}{*}{ Age } & $\leq 20$ years old & 3 \\
\hline & 21-30 years old & 35 \\
\hline & $31-40$ years old & 90 \\
\hline & 41-50years old & 82 \\
\hline & $\geq 51$ years old & 41 \\
\hline \multirow[t]{2}{*}{ Gender } & Man & 26 \\
\hline & Woman & 225 \\
\hline \multirow[t]{2}{*}{ Marital status } & Married & 178 \\
\hline & Single & 73 \\
\hline \multirow[t]{6}{*}{ Last schooling } & Junior high school & 3 \\
\hline & Senior high school & 36 \\
\hline & Diploma 1 & 1 \\
\hline & Diploma 3 & 21 \\
\hline & Undergraduate & 146 \\
\hline & Graduate & 41 \\
\hline \multirow[t]{17}{*}{ Province } & Nanggroe Aceh Darussalam & 1 \\
\hline & North Sumatera & 2 \\
\hline & West Sumatera & 1 \\
\hline & South Sumatera & 2 \\
\hline & Riau & 3 \\
\hline & Riau Islands & 1 \\
\hline & Lampung & 1 \\
\hline & The Special Capital Region of Jakarta & 124 \\
\hline & West Java & 44 \\
\hline & Banten & 45 \\
\hline & Central Java & 6 \\
\hline & East Java & 14 \\
\hline & The Special Region of Yogyakarta & 2 \\
\hline & Bali & 1 \\
\hline & West Kalimantan & 2 \\
\hline & South Kalimantan & 2 \\
\hline & North Sulawesi & 1 \\
\hline \multirow{6}{*}{$\begin{array}{l}\text { Product Purchase } \\
\text { Frequency }\end{array}$} & One time & 92 \\
\hline & Two times & 54 \\
\hline & Three times & 33 \\
\hline & Four times & 17 \\
\hline & Five times & 12 \\
\hline & $\geq$ Six times & 43 \\
\hline
\end{tabular}

\section{The Validity and Reliability Testing Result}

Table 4 shows the final validity result once removing the invalid indicators and reliability test result based on the accurate answer. In this condition, it can be ascertained that all responses are valid because their loading factor is above 0.5 and consistent due to the Cronbach Alpha for each indicator group exceeds 0.70 . 
Table 4. The result of the confirmatory factor analysis and Cronbach Alpha

\begin{tabular}{|c|c|c|c|c|c|}
\hline Variable & Indicator & $\begin{array}{l}\text { Loading } \\
\text { factor }\end{array}$ & Meaning & $\begin{array}{c}\text { Cronbach } \\
\text { Alpha }\end{array}$ & Meaning \\
\hline \multirow{10}{*}{$\begin{array}{l}\text { Service } \\
\text { quality }\end{array}$} & SQ1 & 0.830 & The answer is accurate. & \multirow[t]{10}{*}{0.937} & \multirow{10}{*}{$\begin{array}{l}\text { All the } \\
\text { valid } \\
\text { answers are } \\
\text { consistent. }\end{array}$} \\
\hline & SQ2 & 0.831 & The answer is accurate. & & \\
\hline & SQ3 & 0.661 & The answer is accurate. & & \\
\hline & SQ4 & 0.790 & The answer is accurate. & & \\
\hline & SQ5 & 0.818 & The answer is accurate. & & \\
\hline & SQ6 & 0.823 & The answer is accurate. & & \\
\hline & SQ7 & 0.602 & The answer is accurate. & & \\
\hline & SQ8 & 0.779 & The answer is accurate. & & \\
\hline & SQ9 & 0.801 & The answer is accurate. & & \\
\hline & SQ10 & 0.834 & The answer is accurate. & & \\
\hline \multirow[t]{3}{*}{ Brand trust } & BT1 & 0.756 & The answer is accurate. & \multirow[t]{3}{*}{0.916} & \multirow{3}{*}{$\begin{array}{l}\text { All the } \\
\text { proper } \\
\text { responses } \\
\text { are } \\
\text { consistent. }\end{array}$} \\
\hline & BT2 & 0.773 & The answer is accurate. & & \\
\hline & BT3 & 0.796 & The answer is accurate. & & \\
\hline \multirow{3}{*}{$\begin{array}{l}\text { Brand } \\
\text { Loyalty }\end{array}$} & BL1 & 0.757 & The answer is accurate. & \multirow[t]{3}{*}{0.936} & \multirow{3}{*}{$\begin{array}{l}\text { All the } \\
\text { precise } \\
\text { answers are } \\
\text { consistent. }\end{array}$} \\
\hline & BL2 & 0.733 & The answer is accurate. & & \\
\hline & BL3 & 0.723 & The answer is accurate. & & \\
\hline
\end{tabular}

\section{The Goodness of Fit Model Testing Result}

Table 5 demonstrates the goodness of the fit model test result. The result shows the Chi-Square/DF of 3.185, the parsimony ratio of 0.850 , and the parsimony normed fit index of 0.744 . Besides, the parsimony comparative fit index shows 0.769 . Because four values meet the necessary condition in this table, the model is suitable for the employed data.

Table 5. The goodness of fit model test result

\begin{tabular}{|c|c|c|c|}
\hline Measurement & Value & The required condition & Meaning \\
\hline Chi-square/DF & 3.185 & $\begin{array}{l}\text { The model fits the utilized } \\
\text { data if the Chi-square/DF is } \\
\text { below } 5 \text { (Ghozali, 2014). }\end{array}$ & \multirow[t]{4}{*}{$\begin{array}{l}\text { The model is } \\
\text { suitable for the } \\
\text { employed data. }\end{array}$} \\
\hline $\begin{array}{l}\text { Parsimony ratio } \\
\text { (PRATIO) }\end{array}$ & 0.850 & \multirow{3}{*}{$\begin{array}{l}\text { The model fits the utilized } \\
\text { data if the PRATIO, PNFI, } \\
\text { and PCFI are above } 0.6 \\
\text { (Latan, 2013). }\end{array}$} & \\
\hline $\begin{array}{l}\text { Parsimony normed fit } \\
\text { index (PNFI) }\end{array}$ & 0.744 & & \\
\hline $\begin{array}{l}\text { Parsimony comparative } \\
\text { fit index (PCFI) }\end{array}$ & 0.769 & & \\
\hline
\end{tabular}

\section{The Result of Model Estimation}

Table 6 presents the covariance-based structural equation model estimation result. Also, this table shows the probability value of critical ratio for $\beta_{1}=0.904$ is $* * *$ and $\gamma_{1}=$ 0.967 is $* * *$. This situation means:

a. the first hypothesis declaring a positive influence of brand trust on brand loyalty is verified; 
b. the second research hypothesis stating a positive influence of service quality on brand trust exists is confirmed.

Table 6. The Covariance-based Structural Equation Model Estimation Result

\begin{tabular}{|c|c|c|c|c|}
\hline Hypothesis & Path & $\begin{array}{c}\text { Standardized } \\
\text { path coefficient }\end{array}$ & Critical ratio & $\begin{array}{c}\text { Probability } \\
\text { value }\end{array}$ \\
\hline 1 & BT $\rightarrow$ BL & $\beta_{1}=0.904$ & 11.691 & $* * *$ \\
\hline 2 & SQ $\rightarrow$ BT & $\gamma_{1}=0.967$ & 13.284 & $* * *$ \\
\hline
\end{tabular}

\section{Discussion}

The first hypothesis testing result displays that brand trust has a positive influence on brand loyalty. This positive influence happens because the respondents get something above their brand expectations, count on the Precious One-branded products, and feel pleased with consuming these products. The agreement response for the brand trust-related items is between $84.86 \%$ and $87.65 \%$. By this positive relationship fact, this study is in line with Zehir et al. (2011), Etemadifard et al. (2016), Ahmed et al. (2014), Başer et al. (2015), Ukaj and Mullatahir (2019), Shin et al. (2019), Atulkar (2020), Puspaningrum (2020), and Cuong (2020).

The second hypothesis testing result exhibits that service quality has a positive impact on brand trust. This positive impact occurs because Precious One gives excellent service quality to its customers by fulfilling five aspects, where the agreement response of the indicators is from $77.77 \%$ to $90.04 \%$. The five factors intended are as follows. The first aspect is tangibility, covering the physical environment and the system to handle the customer complaints (see SQ1 and SQ2). The second is responsiveness, demonstrated by employees' quick action to take the customer complaints (see SQ3). The third is reliability, reflected by the punctuality to deliver goods and the excellent order recording system (see SQ4 and SQ5). The fourth is empathy, shown by the time flexibility to order goods and exceptional customer attention (see SQ6 and SQ7). Lastly, the guarantee is the fifth, mirrored by the politeness to serve the customers and knowledge answer their question (see SQ8 and SQ9), and the secure financial transaction (see SQ10). By this positive association evidence between service quality and brand loyalty, this study supports Zehir et al. (2011), Alhaddad (2015), Etemadifard et al. (2016), Esmaeilpour et al. (2017), Ukaj and Mullatahir (2019), Wijaya et al. (2020), and Wijayanti (2020).

\section{Conclusion and suggestion Conclusion}

This study plans to examine and analyze the influence of service quality and brand trust on brand loyalty by surveying the Precious One products' buyers. This study fruitfully proves a positive impact once getting and exploring Precious One's customer perceptions through the survey from July until November 2020. In other words, to elevate the brand's dedication automatically impacted by brand trust, Precious One needs to create superior service.

\section{Suggestion}

Practically, based on this evidence, this study suggests some actions to elevate brand trust to increase brand loyalty by considering service quality aspects.

1. For the tangibility aspect, the method of payment is still by online cash transfer. For many respondents, this way is safe. Unfortunately, this way is still conventional. Therefore, this research suggests that Precious One integrate the order system with 
online payment by credit card in its website as the alternative. By having it, the consumers can choose the payment method based on their preference.

2. The Precious One staff can send special offers with discounts for all customers having a birthday in the current month for the empathy aspect.

3. For the responsiveness aspect, Precious One must set the required time in the standard and operating procedure for the staff to handle the customer orders.

4. For the reliability aspect, Precious One needs to meet customer orders on time and compensate the customers if the delivered goods are not compatible with their order.

5. For the guarantee aspect, Precious One needs to equip the staff members with product comprehension to answer all the customer questions.

Academically, this research restricts the number of the utilized exogenous variables of brand trust determinants. Moreover, to make it better, the following scholars can add exogenous variables, such as brand communication, social networking, community engagement, the management impression, brand utilization, brand experience, brand reputation, brand satisfaction, and perceived value.

\section{References}

Aaker, D. A. (2010). Managing Brand Equity: Capitalizing on the Value of a Brand Name. Jakarta: Spektrum Mitra Utama.

Ahmed, Z., Rizwan, M., Ahmad, M., \& Haq, M. (2014). Effect of brand trust and customer satisfaction on brand loyalty in Bahawalpur. Journal of Sociological Research, 5(1), 306-326. doi:10.5296/jsr.v5i1.6568

Alhaddad, A. (2015). Perceived quality, brand image, and brand trust as determinants of brand loyalty. Journal of Research in Business and Management, 3(4), 1-8. Retrieved from https://www.questjournals.org/jrbm/papers/vol3issue4/A340108.pdf

Al-Rommy, F., \& Murtiningsih, D. (2020). Brand trust sebagai variabel mediasi pengaruh customer relationship management dan service quality terhadap loyalitas mahasiswa. Jurnal Ekonomika dan Manajemen, 9(1), 10-24. Retrieved from https://journal.budiluhur.ac.id/index.php/ema/article/view/1110/812

Atulkar, S. (2020). Brand trust and brand loyalty in-mall shoppers. Marketing Intelligence \& Planning, 38(5), 559-572. doi:10.1108/MIP-02-2019-0095

Başer, İ. U., Cintamür, İ. G., \& Arslan, F. G. (2015). Examining the effect of brand experience on customer satisfaction, brand trust, and brand loyalty. Economics and Administrative Sciences, 37(2), 101-128. doi:10.14780/iibd.51125

Bennur, S., \& Jin, B. (2016). The mediating role of brand trust and affect in clothing brand loyalty formation: a cross-cultural examination of U.S. and India. The Journal of The Textile Institute, 108(1), 1-12. doi:10.1080/00405000.2015.1133105

Cuong, D. T. (2020). The influence of brand satisfaction, brand trust, brand preference on brand loyalty to laptop brands. Systematic Reviews in Pharmacy, 11(11), 95-101. doi:10.31838/srp.2020.11.15

Esmaeilpour, M., Sayadi, A., \& Mirzaei, M. (2017). Investigating the impact of service quality dimensions on reputation and brand trust. International Journal of Business and Economic Sciences Applied Research, 10(3), 7-17. doi:10.25103/ijbesar.103.01

Etemadifard, M., Kafashpoor, A., \& Zendehdel, A. (2016). The effect of brand communication and service quality in the creation of brand loyalty through brand trust (Case study: Samsung's representative company in Mashhad city). 
International Journal of Advanced Studies in Humanities and Social Science, 5(4), 336-346. Retrieved from http://www.ijashss.com/article_83837.html

Ghozali, I. (2014). Structural Equation Model: Concepts and Their Application by AMOS 22.0. Semarang: Badan Penerbit Universitas Diponegoro.

Ghozali, I. (2016). Application of Multivariate Analysis by IBM SPSS 23 (8 ed.). Semarang: Badan Penerbit Universitas Diponegoro.

Giddens, N., \& Hofmann, A. (2010, August). Brand loyalty. Retrieved April 27, 2021, from https://www.extension.iastate.edu/agdm/wholefarm/pdf/c5-54.pdf

Kabadayi, E. T., \& Alan, A. K. (2012). Brand trust and brand affect: Their strategic importance on brand loyalty. Journal of Global Strategic Management, 6(1), 8088. doi:10.20460/JGSM.2012615788

Karam, A. A., \& Saydam, S. (2015). An analysis study of improving brand awareness and its impact on consumer behavior via media in North Cyprus (A case study of fastfood restaurants). International Journal of Business and Social Science, 6(1), 6680. Retrieved from http://ijbssnet.com/journals/Vol_6_No_1_Januaryr_2015/8.pdf

Laroche, M., Habibi, M. R., Richard, M. O., \& Sankaranarayanan, R. (2012). The effects of social media-based brand communities on brand community markers, value creation practices, brand trust, and brand loyalty. Computers in Human Behavior, 28, 1755-1767. doi:10.1016/j.chb.2012.04.016

Latan, H. (2013). Structural Equation Model: Theory and Implementation of AMOS 21.0. Bandung: Alfabeta.

Liao, S. H., Chung, Y. C., Hung, Y. R., \& Widowati, R. (2010). The impacts of brand trust, customer satisfaction, and brand loyalty on word-of-mouth. IEEE International Conference on Industrial Engineering and Engineering Management, (pp. 1319-1323). Macao. doi:10.1109/IEEM.2010.5674402

Prameka, A., Do, B. R., \& Rofiq, A. (2016). How brand trust is influenced by perceived value and service quality: Mediated by hotel customer satisfaction. Asia-Pacific Management and Business Application, 5(2), 73-88. doi:10.21776/ub.apmba.2016.005.02.2

Puspaningrum, A. (2020). Social media marketing and brand loyalty: The role of brand trust. Journal of Asian Finance, Economics and Business, 7(12), 951-958. doi:10.13106/jafeb.2020.vol7.no12.951

Setiadi, N. J. (2019). Perilaku Konsumen (3 ed.). Jakarta: Prenadamedia Group.

Setiawati, I. (2016, February 3). Precious One: Connecting two worlds through handicrafts. Retrieved from https://www.thejakartapost.com/news/2016/02/03/precious-one-connecting-twoworlds-through-handicrafts.html

Shin, S. K. S., Amenuvor, F. E., Basilisco, R., \& Owusu-Antwi, K. (2019). Brand trust and brand loyalty: A moderation and mediation perspective. Current Journal of Applied Science and Technology, 38(4), 1-17. doi:10.9734/CJAST/2019/v38i430376

Sugiyono. (2012). Metode Penelitian Kuantitatif, Kualitatif, dan Kombinasi (Mixed method). Bandung: Alfabeta.

Sulistiyo, T. D. (2015). The influence of brand image, service quality, and perceived value. Jurnal Ilmiah Pariwisata, 20(3), 205-220. Retrieved from http://jurnalpariwisata.stptrisakti.ac.id/index.php/JIP/article/view/37

Tjiptono, F. (2011). Management and Brand Strategy. Yogyakarta: Penerbit ANDI. 
Tjiptono, F. (2019). Service Marketing: Principles, Application, and Research. Yogyakarta: Penerbit ANDI.

Ukaj, F., \& Mullatahir, V. (2019). The relationships among service quality and emarketing with trust and loyalty to brands of mobile telephone operators in Kosovo. Journal of Distribution Science, 17(10), 27-39. doi:10.15722/jds.17.10.201910.27

Wijaya, A. F. B., Surachman, S., Mugiono, M. (2020). The effect of service quality, perceived value, and mediating effect of brand image on brand trust. Jurnal Manajemen \& Kewirausahaan, 22(1), 45-56. doi:10.9744/jmk.22.1.45-56

Wijayanti, C. A. (2020). The influence of service quality and satisfaction on brand loyalty of restaurant of Pizza E-Birra. Klabat Journal of Management, 1(1), 11-42. doi:10.31154/kjm.v1i1.447.11-42

Zehir, C., Kitapçı, H., \& Öz, M. (2011). The effects of brand communication and service quality in building brand loyalty through brand trust. Procedia Social and Behavioral Sciences, 24, 1218-1231. doi:10.1016/j.sbspro.2011.09.142 